\title{
Estrogen receptor- $\alpha$ promoter methylation is a biomarker for outcome prediction of cisplatin resistance in triple-negative breast cancer
}

\author{
JUNNAN XU, TAO SUN, XIANGYU GUO, YAN WANG and MINGXI JING \\ Department of Medical Oncology, Cancer Hospital of China Medical University, \\ Liaoning Cancer Hospital and Institute, Shenyang, Liaoning 110042, P.R. China
}

Received December 9, 2015; Accepted November 2, 2017

DOI: $10.3892 / \mathrm{ol} .2017 .7637$

\begin{abstract}
A number of previous studies have indicated the presence of a link between estrogen receptor- $\alpha(\mathrm{ER} \alpha)$ methylation and triple-negative breast cancer (TNBC). However, the association between ER $\alpha$ methylation and drug resistance during the treatment of TNBC remains unclear. Methylation-specific polymerase chain reaction was used to investigate the methylation of $\mathrm{ER} \alpha$ in the genomic DNA of 35 patients with TNBC who were defined as cisplatin-based chemotherapy-resistant using chemosensitivity testing. Survival probabilities by covariates were assessed using Kaplan-Meier estimator survival analysis and Cox's proportional hazards models, adjusting for age, menopausal status, tumor size, lymph node metastasis and ER $\alpha$ promoter DNA methylation. Of the 35 patients with TNBC analyzed, 8 exhibited ER $\alpha$ promoter DNA methylation. Cisplatin resistance was confirmed to be overwhelmingly associated with ER $\alpha$ methylation by univariate and multivariate analysis. Even in a limited analysis in patients with ER $\alpha$ methylation, the results generated from methylated tumor tissue and unmethylated tumor tissue revealed that expression of breast cancer type $1 / 2$ susceptibility proteins was increased in ER $\alpha$-methylated breast tumor tissue compared with in unmethylated tissue. The $\mathrm{ER} \alpha$ methylation group tended to have significantly shorter progression-free $(\mathrm{P}=0.010)$ and overall $(\mathrm{P}=0.023)$ survival times compared with those in the unmethylated group. Similarly, shorter progression-free $(\mathrm{P}=0.024)$ and overall $(\mathrm{P}=0.018)$ survival times were observed in the cisplatin-resistant group compared with the cisplatin-non-resistant group. $\mathrm{ER} \alpha$ methylation predicts a poor clinical outcome for patients
\end{abstract}

Correspondence to: Professor Mingxi Jing, Department of Medical Oncology, Cancer Hospital of China Medical University, Liaoning Cancer Hospital and Institute, 44 Xiaoheyan Road, Dadong, Shenyang, Liaoning 110042, P.R. China

E-mail: jingmx@163.com

Key words: triple-negative breast cancer, estrogen receptor- $\alpha$ methylation, breast cancer 1 , drug resistance, cisplatin with TNBC. The results of the present study indicated that $\mathrm{ER} \alpha$ methylation may be a candidate surrogate biomarker for outcome prediction and cisplatin resistance in TNBC. Further investigation is required to identify potential biomarkers in a larger cohort in a prospective study.

\section{Introduction}

Breast cancer is the most common type of cancer among women and the fifth most common cause of mortality from cancer in China (1). Triple-negative breast cancer (TNBC) accounts for between 10 and $17 \%$ of cases of breast cancer $(2,3)$. TNBC is an immunohistochemical description of breast cancer characterized by negative staining for estrogen receptor (ER), progesterone receptor (PR) and human epidermal growth factor receptor 2 (HER2) (4). TNBC is associated with younger women and with an increased risk of visceral and/or central nervous system metastases during the first 1-3 years of follow-up following diagnosis (5). Owing to the underlying biological heterogeneity within TNBC and lack of special target therapy, the concept of a standard approach to TNBC treatment is inappropriate (6). TNBC is always more shared in individuals harboring mutations of breast cancer type $1 / 2$ susceptibility proteins (BRCA1/2), and aberrations in BRCA $1 / 2$ may sensitize breast cancer cells to cisplatin (7). The addition of cisplatin significantly improved survival times in unselected patients in 1988, with other studies confirming activity for cisplatin when used as first-line chemotherapy in TNBC (8-10). Results indicated that the combination of gemcitabine and cisplatin gave a favorable clinical response and managed toxicity as a first-line chemotherapeutic agent in patients with metastatic TNBC, in particular patients with the basal-like disease subtype (8). However, the molecular mechanisms underlying cisplatin sensitivity and cisplatin resistance in TNBC are unclear. Previous studies have demonstrated that platinum-based combination chemotherapy may represent an optimum treatment in TNBC, particularly when patients received anthracycline and/or taxanes, or exhibit homogeneous DNA damage repair defections $(9,11)$. Although promising, treatment with cisplatin-based combination therapies faces certain hurdles, 
including the mechanism of platinum resistance and lack of biomarkers to predict responses to cisplatin $(12,13)$.

Methylation of the ER $\alpha$ promoter has previously been demonstrated to be associated with sporadic TNBC, ranging between 30 and $40 \%$ in breast cancer samples. It has been demonstrated that methylation of the ER $\alpha 1, \mathrm{ER} \alpha 3, \mathrm{ER} \alpha 4$ or ER $\alpha 5$ promoters is associated with basal-like breast cancer (14). ER $\alpha$ and BRCA1 promoter methylation may contribute to poor disease-free survival (DFS) and overall survival (OS) times. Fanconi anemia complementation group $\mathrm{F}$ (FANCF) promoter methylation in its $\mathrm{CpG}$ islands caused the inactivation of FANCF and acquired cisplatin resistance during tumor progression in ovarian tumors (15). It is not clear whether the ER $\alpha$ methylation would have a similar effect to that in FANCF, causing primary cisplatin resistance in TNBC. To investigate this hypothesis, ER $\alpha$ methylation in the same panel of primary or recurrent breast tumor samples from patients with breast cancer was measured; subsequently, a cisplatin sensitivity test was conducted and the association between ER $\alpha$ methylation and cisplatin resistance was evaluated. To the best of our knowledge, the present study is the first to be designed to identify ER $\alpha$ methylation markers of resistance in patients with TNBC.

\section{Materials and methods}

Patient materials. Between March 2013 and July 2015, 35 women (median age, 47 years; range, 27-69 years) with TNBC were enrolled in the present study. Primary breast tumor tissues or recurrent breast tumor tissues were obtained by surgical resection at the Department of Breast Surgery or Department of Medical Oncology, Liaoning Cancer Hospital and Institute (Shenyang, China). Tissue sections containing $>30 \%$ tumor cells were selected to detect drug sensitivity including more than eight protocols, based on the National Comprehensive Cancer Network guidelines (16), including cisplatin-based chemotherapy with MTT methods. The association between cisplatin resistance in vitro and clinicopathological characteristics was analyzed in patients with TNBC. Tumor tissues immunohistochemically identified as TNBC were identified as ER-negative (threshold value, 1\%) (sc-542, Santa Cruz, 1:200), PR-negative (sc-539, Santa Cruz, 1:250) and HER2-negative [immunohistochemistry (IHC, sc-08, Santa Cruz, 1:500) 0/1+, or IHC 2+/fluorescence in situ hybridization (Hercep TestTM, DAKP A/S, Glostrup, Denmark) non-amplified from the archived pathological reports in the Liaoning Cancer Hospital and Institute]. The present study used research protocols approved by the Liaoning Cancer Hospital and Institute. All samples were obtained with the patient's informed consent. Diagnoses were confirmed by review of clinicopathological features; the clinical data collected included age, family histology, tumor grade, hormone receptor status, lymph node status and tumor size.

Methylation-specific polymerase chain reaction (PCR) (MSP). DNA extract of ER $\alpha 1, \mathrm{ER} \alpha 3, \mathrm{ER} \alpha 4$ and ER $\alpha 5$ was isolated from tumor tissues using phenol/chloroform extraction and ethanol precipitation in high-solubility SDS/proteinase $\mathrm{K}$ solution. DNA concentration was qualified by determination of optical density (OD) $)_{260 / 280}$ and amplified with specific unmethylated and methylated sequences primers using MSP. Sodium bisulfite-treated DNA was amplified using methylation- and unmethylation-specific primers (presented in Table I) and designated $\mathrm{M}$ label and $\mathrm{U}$ label, respectively. A total of $2 \mu \mathrm{g}$ DNA was denatured using $\mathrm{NaOH}$ (final concentration, $0.2 \mathrm{M}$ ) for $10 \mathrm{~min}$ at $37^{\circ} \mathrm{C}$. For samples with $2 \mu \mathrm{g}$ DNA, salmon sperm DNA (Sigma Aldrich; Merck KgaA, Darmstadt, Germany) was added as carrier prior to modification. A total of $30 \mu \mathrm{l}$ of $10 \mathrm{mM}$ hydroquinone (Sigma Aldrich; Merck KGaA) and $3 \mathrm{M}$ sodium bisulfite (Sigma Aldrich; Merck KGaA) at pH 5 were added and mixed, and samples were incubated under mineral oil at $50^{\circ} \mathrm{C}$ for $16 \mathrm{~h}$. ER $\alpha 1, \mathrm{ER} \alpha 3, \mathrm{ER} \alpha 4$ and $\mathrm{ER} \alpha 5$ for MSP using the six primer pairs as described previously (14) and purified using the Promega Wizard Genomic DNA Purification kit (A1120, Promega Corporation, Madison, WI, USA). The positive control consisted of alleles from healthy volunteers methylated with SssI methyltransferase (New England Biolabs, Inc., Ipswich, MA, USA), and the negative control was modified using RNA-free water. PCR amplification was performed with the reaction mixtures including $12.5 \mu 1$ Premix Taq with $1 \mu \mathrm{l}(20 \mu \mathrm{M})$ of each primer and $100 \mathrm{ng}$ bisulfite-modified DNA template, with a final volume of $25 \mu \mathrm{l}$. The thermocycling conditions were: Denaturation by heating to $95^{\circ} \mathrm{C}$ for $10 \mathrm{~min}$, followed by 14 amplification cycles of $94^{\circ} \mathrm{C}$ for $30 \mathrm{sec}$, $62^{\circ} \mathrm{C}(\mathrm{ER} \alpha 1)$ or $59^{\circ} \mathrm{C}(\mathrm{ER} \alpha 3, \mathrm{ER} \alpha 4$ and $\mathrm{ER} \alpha 5)$ for $45 \mathrm{sec}$ $\left(-0.5^{\circ} \mathrm{C}\right.$ decreased/cycle) and $72^{\circ} \mathrm{C}$ for $45 \mathrm{sec}$, ending with a final extension of $72^{\circ} \mathrm{C}$ for $10 \mathrm{~min}$. The PCR products were separated on a $1 \%$ agarose gel stained with GeneFinder ${ }^{\mathrm{TM}}$ and images captured by Fluorchem 5500 (ProteinSimple, San Jose, CA, USA). Methylation was considered to be present if the methylated label was detected.

Drug-sensitivity test in vitro. The drug sensitivity of surgical biopsy or surgical excision tissues was assessed using an MTT assay. The primary or recurrent breast cancer tissues were collected from each patient immediately following surgical removal. The cancer cells were digested from tissues and cultured in Dulbecco's modified Eagle's medium (Gibco; Thermo Fisher Scientific, Inc., Waltham, MA, USA) with $10 \%$ fetal bovine serum (SH30084.03, Hyclone, Thermo Fisher Scientific, Inc.) at $37^{\circ} \mathrm{C}$ with $5 \% \mathrm{CO}_{2}$, and were used in the exponential phase of growth. Cultured cells were treated with cisplatin (A14200156601, QILU Pharmaceutical) at a final concentration of $0.2 \mathrm{mg} / \mathrm{ml}$, for 24 or $48 \mathrm{~h}$. Drug sensitivity was evaluated using an MTT assay. A total of $150 \mu \mathrm{l}$ MTT solution (Sigma Aldrich; Merck KGaA) at concentration of $5 \mathrm{mg} / \mathrm{ml}$ was added for $2 \mathrm{~h}$ at $37^{\circ} \mathrm{C}$. After removing the supernatant, $150 \mathrm{ml}$ DMSO (Sigma Aldrich; Merck KGaA) was added to each well for absorbance reading at a wavelength of $490 \mathrm{~nm}$ using a plate reader (Tecan Sunrise $^{\mathrm{TM}}$, Tecan Group Ltd., Männedorf, Switzerland).

Western blotting. The proteins from breast cancer tissues were extracted using a Tissue or Cell Total Protein Extraction Kit (C510003; Sangon Biotech Co., Ltd., Shanghai, China). Protein content was determined by the Lowry method using bovine serum albumin as the standard. The samples containing $100 \mu \mathrm{g}$ proteins were separated via SDS-PAGE (10\% gel). Following transfer to polyvinylidene fluoride membranes, the samples were blocked using 5\% skim milk powder in TBS-T $(30 \mathrm{mM}$ Tris- $\mathrm{HCl}, 125 \mathrm{mM} \mathrm{NaCl}, 0.1 \%$ Tween 20) for $1 \mathrm{~h}$ at room 
Table I. Primer pair sequences of ER $\alpha 1, \mathrm{ER} \alpha 3, \mathrm{ER} \alpha 4$ and $\mathrm{ER} \alpha 5$.

\begin{tabular}{|c|c|c|c|}
\hline Name & Primer pair sequences & Size, bp & Site $^{a}$, bp \\
\hline $\mathrm{ER} \alpha 1 \mathrm{U}$ & $\begin{array}{l}\text { 5'-TTTTGGGATTGTATTTGTTTTTGTTG-3' } \\
\text { 5'-AAACAAAATACAAACCATATCCCCA-3' }\end{array}$ & 192 & +44 \\
\hline $\mathrm{ER} \alpha 1 \mathrm{M}$ & $\begin{array}{l}\text { 5'-TTTTGGGATTGTATTTGTTTTCGTC-3' } \\
\text { 5'-AACAAAATACAAACCGTATCCCCG-3' }\end{array}$ & 192 & +236 \\
\hline $\mathrm{ER} \alpha 3 \mathrm{U}$ & $\begin{array}{l}\text { 5'-GGATATGGTTTGTATTTTGTTTGT-3' } \\
\text { 5'-ACAAACAATTCAAAAACTCCAACT-3' }\end{array}$ & 120 & +225 \\
\hline $\mathrm{ER} \alpha 3 \mathrm{M}$ & $\begin{array}{l}\text { 5'-GATACGGTTTGTATTTTGTTCGC-3' } \\
\text { 5'-CGAACGATTCAAAAACTCCAACT-3' }\end{array}$ & 130 & +345 \\
\hline $\mathrm{ER} \alpha 4 \mathrm{U}$ & $\begin{array}{l}\text { 5'-ATGAGTTGGAGTTTTTGAATTGTTT-3' } \\
\text { 5'-ATAAACCTACACATTAACAACAACCA-3' }\end{array}$ & 158 & +310 \\
\hline $\mathrm{ER} \alpha 4 \mathrm{M}$ & $\begin{array}{l}\text { 5'-CGAGTTGGAGTTTTTGAATCGTTC-3' } \\
\text { 5'-CTACGCGTTAACGACGACCG-3' }\end{array}$ & 151 & +468 \\
\hline $\mathrm{ER} \alpha 5 \mathrm{U}$ & $\begin{array}{l}\text { 5'-GGTGTATTTGGATAGTAGTAAGTTTGT-3' } \\
\text { 5'-CCATAAAAAAAACCAATCTAACCA-3' }\end{array}$ & 120 & +375 \\
\hline $\mathrm{ER} \alpha 5 \mathrm{M}$ & $\begin{array}{l}\text { 5'-GTGTATTTGGATAGTAGTAAGTTCGTC-3' } \\
\text { 5'-CGTAAAAAAAACCGATCTAACCG-3' }\end{array}$ & 118 & +495 \\
\hline
\end{tabular}

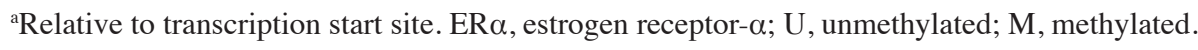

temperature. The PVDF membranes were incubated with the primary antibody, specific to either P-glycoprotein (P-gp; cat no. sc-55510; 1:1,500; Santa Cruz Biotechnology, Inc., Dallas, TX, USA) or BRCA1 (cat no. ab9141; 1:500; Abcam, Cambridge, UK) overnight at $4^{\circ} \mathrm{C}$. After washing, the blots were incubated with peroxidase-conjugated affinity-purified goat anti-mouse or goat anti-rabbit secondary antibody (1:1,500; cat nos. sc-395758 and sc-45101, respectively; Santa Cruz Biotechnology, Inc.), as appropriate. Band density of P-gp or BRCA1 was scanned and measured using Fluorchem 5500 software (Alpha Innotech Co., San Leandro, CA, USA). The column ratios were determined through scanned $\beta$-actin as calibration.

Statistical analysis. All statistical data are presented as the mean \pm standard deviation and the data analyses were performed using SPSS for Windows (version 13.0; SPSS, Inc., Chicago, IL, USA). A $\chi^{2}$ test and Fisher's exact test were used for binary variable comparisons. PFS and OS curves were constructed using the Kaplan-Meier method and a log-rank test was used to perform comparisons between patients with or without ER- $\alpha$ promoter methylation and cisplatin resistance. Factors influencing cell inhibition by cisplatin, including ER- $\alpha$ promoter methylation and other prognostic factors, were investigated through univariate logistic regression and Cox's proportional hazards regression model with hazards ratio (HR) calculation with $95 \%$ confidence interval $(95 \% \mathrm{CI})$. $\mathrm{P}<0.05$ was considered to indicate a statistically significant difference. OS time was calculated from initiation of treatment to mortality, and individuals alive were censored at the time of last follow-up.

\section{Results}

Cisplatin resistance in drug-sensitivity test and association with clinicopathological characteristics. Between 1 March
2013 and 30 July 2015, 35 women with TNBC, with a median age of 47 years (range, 27-69 years), were enrolled. Baseline characteristics of the patients were well-balanced between the drug-sensitivity groups. The drug-sensitivity test including assessment of sensitivity to cisplatin alone and in combination with gemcitabine or capecitabine in all 35 patients with TNBC. Primary cancer cells from patients with TNBC were exposed to various concentrations of cisplatin (final concentration, $0.2 \mu \mathrm{g} / \mathrm{ml}$ ) for $48 \mathrm{~h}$. On the basis of the threshold of the majority of drugs in the antitumor drug-sensitivity test in vitro, cells whose proliferation was decreased by $\leq 30 \%$ were defined as cisplatin-resistant. Using this definition, the results in vitro indicated that 23 individuals exhibited cisplatin sensitivity (inhibition ratio of breast cancer cell, $>30 \%$ ) and 12 patients exhibited cisplatin resistance. The inhibition rate of primary breast cancer cells from premenopausal patients was $47.12 \%$ and that of primary breast cancer cells from postmenopausal patients was $44.79 \%$. Cisplatin resistance in vitro occurred more often in cells from postmenopausal patients, patients negative for lymph node metastasis (cell inhibition ratio, 51.24 vs. $40.78 \%$ for lymph node metastasis-positive and -negative tissues, respectively) and larger tumor size group (cell inhibition ratio, 49.15 vs. $43.91 \%$ for tumor sizes $<2 \mathrm{~cm}$ and $>2 \mathrm{~cm}$, respectively). However, the differences in tumor size, lymph node metastasis status, age and menopausal status were not significant (Table II). All of the patients with ER $\alpha$ methylation $(\mathrm{n}=8)$ exhibited cisplatin insensitivity in vitro. Cell inhibition ratios were $20.25 \%$ in the $\mathrm{ER} \alpha$-methylated group and $53.44 \%$ in the ER $\alpha$-unmethylated group. The multivariate Cox's model yielded results for the following: Arm 1, age <40 years; age $>40$ years [hazard ratio (HR), $0.715 ; 95 \%$ confidence interval (CI), 0.30-1.70; $\mathrm{P}=0.715]$; arm 2, premenopausal vs. postmenopausal (HR, 0.850; 95\% CI, 0.37-1.97; $\mathrm{P}=0.711$ ); arm 3, tumor size $<2 \mathrm{~cm}$ vs. tumor size $>2 \mathrm{~cm}$ (HR, 0.850; 95\% CI, 0.38-1.93; $\mathrm{P}=0.698)$; arm 4 , lymph node metastasis-positive vs. lymph node 
Table II. Univariate and multivariate model for cell inhibition by cisplatin in TNBC.

\begin{tabular}{|c|c|c|c|c|c|c|}
\hline \multirow[b]{2}{*}{ Factor } & \multirow[b]{2}{*}{ Patients, $\mathrm{n}$} & \multicolumn{2}{|c|}{$\begin{array}{c}\text { Univariate } \\
\text { Cell inhibition ratio }\end{array}$} & \multicolumn{3}{|c|}{$\begin{array}{c}\text { Multivariate } \\
\text { Cell inhibition ratio }\end{array}$} \\
\hline & & Mean, $\%$ & P-value & OR & $95 \% \mathrm{CI}$ & P-value \\
\hline Age, years & & & 0.594 & & & 0.715 \\
\hline$<40$ & 20 & 40.40 & & 0.715 & $0.30-1.70$ & \\
\hline$\geq 40$ & 15 & 53.13 & & & & \\
\hline Menopausal status & & & 0.693 & & & 0.711 \\
\hline Premenopausal & 19 & 47.12 & & 0.85 & $0.37-1.97$ & \\
\hline Postmenopausal & 16 & 44.79 & & & & \\
\hline Tumor size, cm & & & 0.970 & & & 0.698 \\
\hline$<2$ & 13 & 49.15 & & 0.85 & $0.38-1.93$ & \\
\hline$\geq 2$ & 22 & 43.91 & & & & \\
\hline LNM & & & 0.182 & & & 0.155 \\
\hline Positive & 18 & 51.24 & & 1.66 & $0.83-3.33$ & \\
\hline Negative & 17 & 40.78 & & & & \\
\hline ER $\alpha$ methylation & & & 0.000 & & & $<0.001$ \\
\hline Positive & 8 & 20.25 & & 19.41 & $4.86-77.53$ & \\
\hline Negative & 27 & 53.44 & & & & \\
\hline
\end{tabular}

OR, odds ratio; CI, confidence interval; LNM, lymph node metastasis; ER $\alpha$, estrogen receptor- $\alpha$.

metastasis-negative (HR, 1.66; 95\% CI, 0.83-3.33; $\mathrm{P}=0.155)$; arm 5, ER $\alpha$ methylation vs. ER $\alpha$ unmethylation (HR, 19.41; 95\% CI, 4.86-77.53; $\mathrm{P}<0.001)$.

Analysis of ER $\alpha$ methylation and cisplatin resistance in TNBC. Bisulfite-treated DNA was amplified with specific primers for $\mathrm{ER} \alpha$. If one or more regions were positive for MSP in the methylation labels ER $\alpha 1, \mathrm{ER} \alpha 3, \mathrm{ER} \alpha 4$ and $\mathrm{ER} \alpha 5$, the tumor tissue was considered to be ER $\alpha$-methylated. As presented in Fig. 1, neither ER $\alpha$ methylation nor unmethylation were observed in the negative control group; however, the ER $\alpha$ methylation lane was present in positive group. This result demonstrated that MSP had sensitivity and specificity for the present study. In the 35 tumor tissue samples, 8/35 (22.9\%) of specimens were ER $\alpha$-methylated (Fig. 1). The formulation of ER $\alpha$ methylation varied in the samples. ER $\alpha 1$ methylation was positive in four samples (J3, J8, J17 and J34), ER3 methylation was observed in 7/8 positive samples (J1, J3, J5, J19, J23 and J34), ER $\alpha 4$ methylation was positive in three samples (J5, J8 and J23) and $\mathrm{ER} \alpha 5$ methylation was observed in three samples (J8, J17 and J23). ER $\alpha 3$ methylation was the most widely shared among these samples. All eight samples with ER $\alpha$ methylation were resistant to cisplatin. The results of this analysis indicated that $\mathrm{ER} \alpha$ methylation was significantly associated with cisplatin resistance in vitro. However, the formation and degree of methylation was not associated with cell prohibition by cisplatin in the ER $\alpha$ methylation group. ER $\alpha$ methylation may serve an important role in primary cisplatin resistance in TNBC.

ERa methylation promotes cisplatin resistance in TNBC by BRCA overexpression. To determine the contribution of the multidrug-resistance protein P-gp and BRCA1 to primary cisplatin resistance induced by ER $\alpha$ methylation, western blot analysis was performed on primary cancer cells obtained from patients. As presented in Fig. 2A, ER $\alpha$ methylation was associated with an increase in the protein expression of BRCA1, whereas the protein expression level of P-gp was not associated with ER $\alpha$ methylation. These results provide evidence that $\mathrm{ER} \alpha$ methylation promotes cisplatin resistance in vitro via the overexpression of BRCA, rather than P-gp.

Clinical prognosis of patients in vivo. A total of 35 patients, for whom the ER $\alpha$ methylation characteristics were known, were assessed (Fig. 3). As presented in Fig. 3A and C, a significant decrease in ER $\alpha$ methylation was identified in PFS and OS rates. A similar pattern was observed for cisplatin resistance: A significant decrease in PFS rate was observed in patients with cisplatin resistance for the follow-up duration (Fig. 3B). As presented in Fig. 3D, OS rate with cisplatin resistance gradually increased in the first 12 months of follow-up, however, the curve exhibited a significantly decreased OS rate in the subsequent months. Between the two survival curves there is a marked crossover. The median PFS time for patients with ER $\alpha$ methylation was 3 months, compared with 6 months for those in the ER $\alpha$-unmethylated arm. The median OS time was similar between the two groups: 14 months in ER $\alpha$ methylation-positive arm and 20.5 months in the ER $\alpha$ methylation-negative arm. The median PFS and OS times of patients with cisplatin resistance were 3 and 16 months, respectively, compared with 7 months and 21.5 months for those in the cisplatin-sensitive arm. 


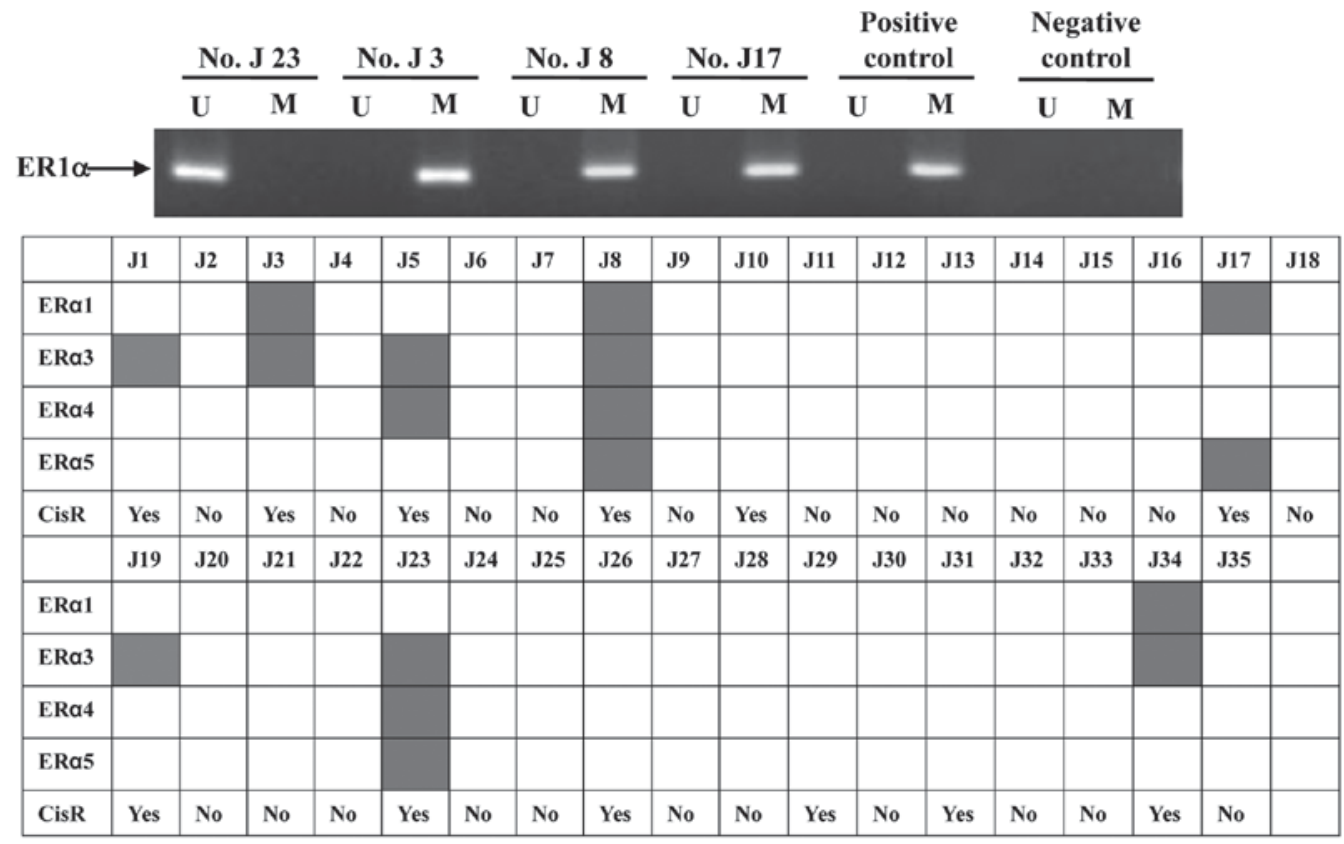

$\mathrm{U}$, unmethylation; M, methylation; CisR, Cisplatin resistant; $\mathbf{m}$ Represents methylation of ER $\alpha$.

Figure 1. Methylation of the ER $\alpha$ gene promoter in TNBC. Methylation of the ER $\alpha 1, \mathrm{ER} \alpha 3, \mathrm{ER} \alpha 4$ and ER $\alpha 5$ gene promoters was analyzed by methylation-specific polymerase chain reaction in TNBC. ER $\alpha$ methylation was present in samples shaded dark grey. Negative control and positive control in the figure represent water and positive methylation-treated DNA, respectively. ER $\alpha$, estrogen receptor- $\alpha$; U, unmethylated; M, methylated; TNBC, triple-negative breast cancer; CisR, cisplatin-resistant.
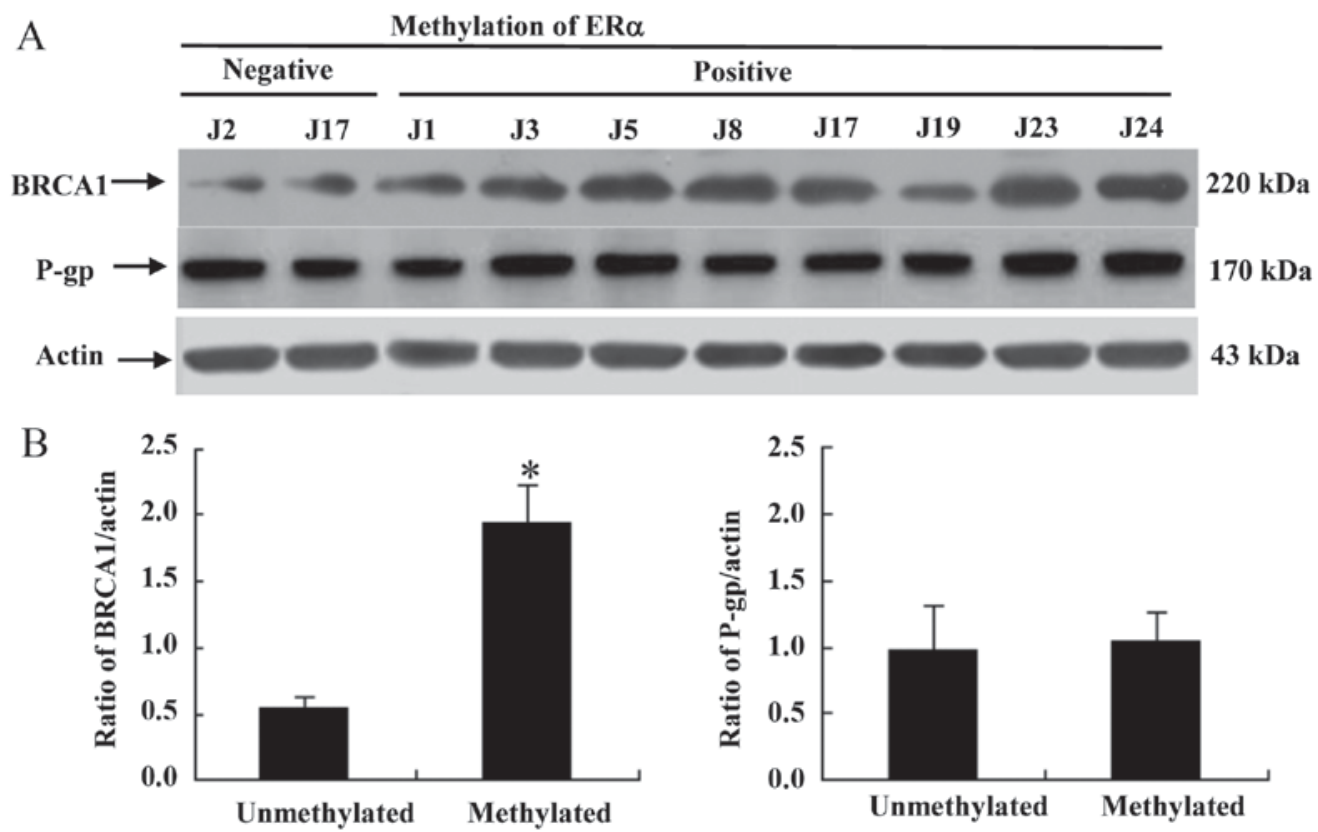

Figure 2. ER $\alpha$ methylation increases the protein expression of BRCA1, but not P-gp, in patients with triple-negative breast cancer. (A) Western blot analysis of BRCA1 and P-gp expression levels in tumor tissues from patients with ER $\alpha$ methylation and ER $\alpha$ unmethylation. Equal amounts of total protein (100 $\mu \mathrm{g})$ were detected and $\beta$-actin protein expression was used as control. (B) Representative results of calculated BRCA1 and P-gp obtained from all the ER $\alpha$ methylation subgroup and $\mathrm{ER} \alpha$ unmethylation subgroup. Data are presented as relative to ER $\alpha$ unmethylation. ${ }^{*} \mathrm{P}<0.05$ vs. ER $\alpha$ unmethylation. BRCA1, breast cancer type 1 susceptibility protein; P-gp, P-glycoprotein; ER $\alpha$, estrogen receptor- $\alpha$.

\section{Discussion}

Breast cancer cells accumulate genetic and protein changes that allow them to evade chemotherapeutic drugs and cause increasingly higher risks to patients, particularly in those with TNBC $(3,4)$. In view of effective specific target, compared with endocrine therapy in hormone-positive breast cancer or transtuzumab therapy in HER2-positive breast cancer, there is no preferred standard chemotherapy to prohibit the proliferation of cancer cells and their metastasis in patients with TNBC (8,17-19). Accurate identification of TNBC and adequately powered prospective trials are required to identify 

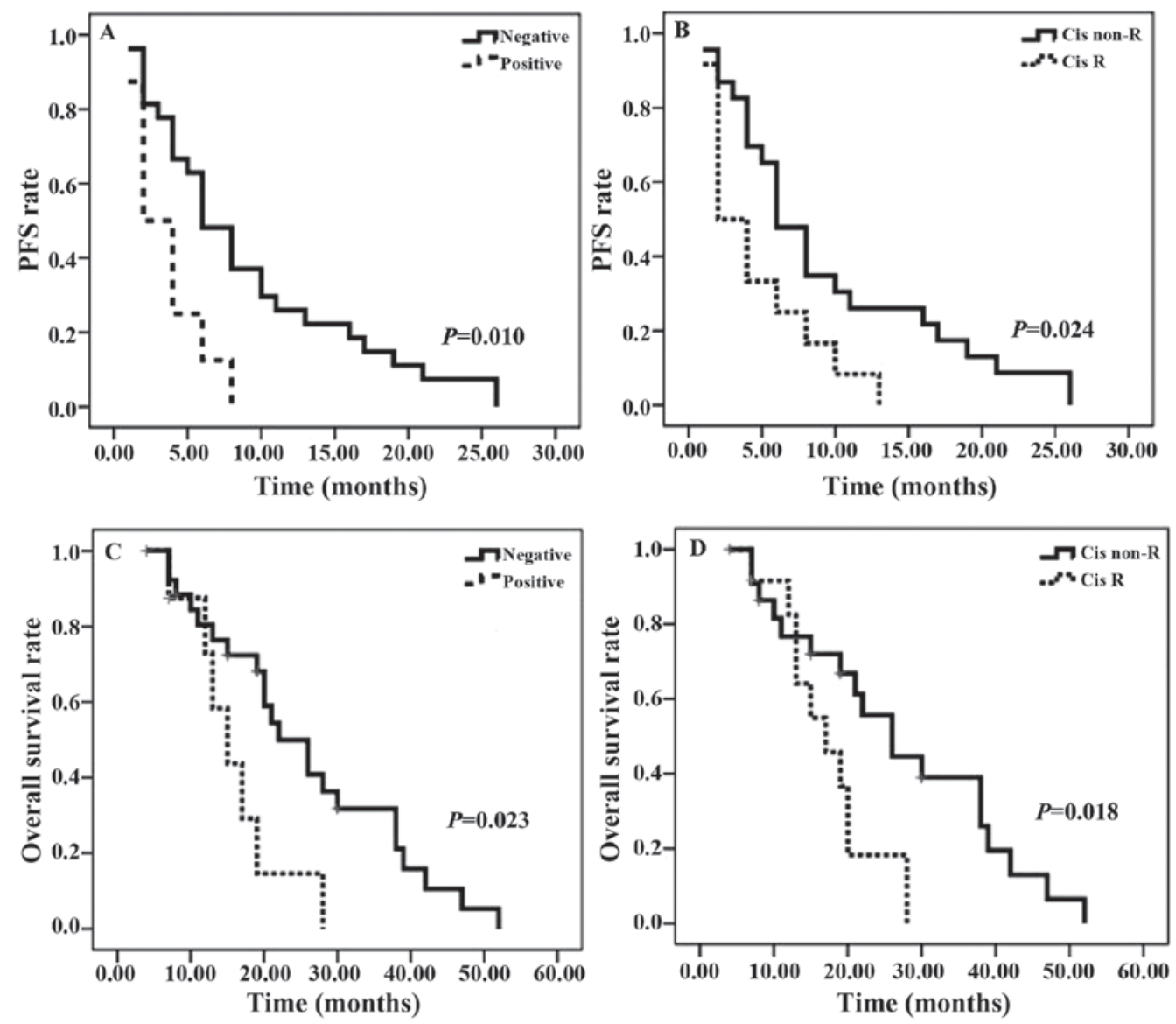

Figure 3. Kaplan-Meier estimator curves for PFS and OS rates in patients with triple-negative breast cancer in the ER $\alpha$ methylation and cisplatin-resistant groups. An event is defined as disease progression for mortality without progression in PFS and as mortality from any cause in OS. (A) PFS ER $\alpha$ methylation and non-methylation groups. (B) PFS cisplatin-resistant and -non-resistant groups. (C) OS ER $\alpha$ methylation and non-methylation groups. (D) OS cisplatin-resistant and -non-resistant groups. In (A) and (C), negative ER $\alpha$ methylation is indicated by a continuous line and positive ER $\alpha$ methylation is indicated by a broken line. In (B) and (D), cisplatin non-resistance is indicated with a continuous line and cisplatin resistance is indicated with a broken line. PFS, progression-free survival; OS, overall survival.

effective chemotherapy regimens and to assess the validity of biomarkers. TNBC accounts for $\sim 15 \%$ of all invasive breast cancers with higher histological grade compared with that in other types of molecular cancer (4).

A number of studies indicate that the weekly addition of paclitaxel to an anthracycline-containing adjuvant therapy may be superior to only anthacycline-containing regimens without paclitaxel; however, the DFS time remained shorter for TNBC compared with non-TNBC $(20,21)$. On the basis of this inhibitory effect on the proliferation of breast cancer cells in mouse models, particularly in the dysfunction of BRCA1 and its pathway, the use of cisplatin to treat TNBC is currently being assessed in clinical trials and certain studies $(7-8,22)$. In neoadjuvant chemotherapy, the use of cisplatin with docetaxel exhibited a higher pathological complete response in patients with BRCA1 mutations (23). In metastatic TNBC, compared with docetexal, carboplatin exhibited significant improvements in the rate of tumor response ( 68.0 vs. $33.3 \%$, respectively; $\mathrm{P}=0.03)$, median PFS times were 6.8 months $(24,25)$. Similarly, the use of olaprib, an oral poly(ADP-ribose) polymerase (PARP) inhibitor, resulted in tumor regression in $<41 \%$ in patients carrying BRCA1 mutations (22). The tumors from patients with TNBC tend to carry different tumor protein mutations, and tumor protein p53 (TP53) and BRCA1 mutations have been described as the most dangerous mutant in breast cancer (26-29).

Patients with mutations in BRCA1 exhibit deficiencies in double-stranded DNA break repair; those with germline BRCA1 mutations have a 20 -fold increased risk of breast cancer, with more aggressive carcinogenesis and angiogenesis (30-32). If patients harbor these mutations, the effective response rate to cisplatin was potentially higher compared with that for other chemotherapy regimens $(22,33)$.

Previous results indicated that ER $\alpha$ methylation was associated with tumor stage, lymph node metastasis, nuclear accumulation of p53 and BRCA1 expression in basal-like breast cancer (14,34-37). The mechanism of action of cisplatin in breast cancer cells with DNA repair dysfunctions remains unknown. The present study indicates that ER $\alpha$ methylation was significantly associated with cisplatin resistance. Previous studies have been searching for and identifying other biomarkers and pathways involved in $\operatorname{TNBC}(38,39)$. However, non-validated biomarkers were explicated to evaluate chemotherapy efficacy (40). The present study identified that ER $\alpha$ methylation may be a meaningful biomarker for the evaluation of cisplatin resistance. However, it is not clear whether $\mathrm{ER} \alpha$ methylation is a biomarker for PARP inhibitors, which, like cisplatin, target DNA repair. No significant difference in 
the expression level of P-gp, which serves an important role in multidrug resistance, was identified. However, it should be noted that there was an association between ER $\alpha$ methylation and overexpression of BRCA1. Patients overexpressing BRCA1 exhibit increased DNA repair function (41-44). There are certain possible explanations for the puzzling effect of $\mathrm{ER} \alpha$ methylation on the overexpression of BRCA. One may be the effect on ataxia telangiectasia mutated (ATM) protein by ER $\alpha$ methylation: It has been proposed that ATM inhibition by the normal ER may provide a strategy to sensitize tumors to DNA-damaging agents including cisplatin (45). Low ER-expression in patients with ER $\alpha$ methylation may partially counteract ATM inhibition (46,47). In addition, elevated BRCA expression was demonstrated to upregulate ATM-associated DNA double-strand break repair $(48,49)$. Other studies indicated that homogenous repair genes were dysregulated and BRCA was overexpressed in patients with breast cancer $(50,51)$. Notably, BRCA overexpression has been associated with poor outcomes in patients with TNBC (52). Despite this, there was not enough evidence to conclude that ER $\alpha$ methylation directly affects DNA repair in the present study.

The results of the present study require confirmation in clinical trials, as well as in other breast cancer types and different tumors. However, these results may dictate valid therapy. The results of the present study may lead to alteration of the therapy regimens in patients with $\mathrm{ER} \alpha$ methylation in TNBC. If clinical trials confirm the results of the present study, patients with TNBC with methylated ER $\alpha$ may benefit from other chemotherapy in place of cisplatin to avoid cisplatin resistance.

In conclusion, the results of the present study indicated that ER $\alpha$ methylation affected not only the sensitivity of breast cancer cells to cisplatin, but also the expression of BRCA1 protein. Further analysis of the mechanism of ER $\alpha$ methylation in cisplatin resistance may aid the development of a novel therapeutic approach to targeting the BRCA1-related signal pathway.

\section{Acknowledgements}

The present study was supported by the Liaoning Province Doctor Startup Fund Program (grant no. 20121132 and 201501108), National Nature Science Foundation (grant no.81502188), CentralGuidance forSpecialFunds(2016007011) and the Clinical Capability Construction Project for Liaoning Provincial Hospitals (grant no. LNCCC-C05-2015).

\section{References}

1. Marmé $\mathrm{F}$ and Schneeweiss A: Targeted therapies in triple-negative breast cancer. Breast Care 10: 159-166, 2015.

2. Schmadeka R, Harmon BE and Singh M: Triple-negative breast carcinoma: Current and emerging concepts. Am J Clin Pathol 141: 462-477, 2014.

3. Elsamany S and Abdullah S: Triple-negative breast cancer: Future prospects in diagnosis and management. Med Oncol 31: 834, 2014.

4. Merlin JL, Harlé A, Lion M, Ramacci C and Leroux A: Expression and activation of P38 MAP kinase in invasive ductal breast cancers: Correlation with expression of the estrogen receptor, HER2 and downstream signaling phosphorylated proteins. Oncol Rep 30: 1943-1948, 2013.

5. Bachmann C, Schmidt S, Staebler A, Fehm T, Fend F, Schittenhelm J, Wallwiener D and Grischke E: CNS metastases in breast cancer patients: Prognostic implications of tumor subtype. Med Oncol 32: 400, 2015.
6. Cho EY, Chang MH, Choi YL, Lee JE, Nam SJ, Yang JH, Park YH, Ahn JS and Im YH: Potential candidate biomarkers for heterogeneity in triple-negative breast cancer (TNBC). Cancer Chemother Pharmacol 68: 753-761, 2011.

7. Lips EH, Mulder L, Oonk A, van der Kolk LE, Hogervorst FB, Imholz AL, Wesseling J, Rodenhuis $\mathrm{S}$ and Nederlof PM: Triple-negative breast cancer: BRCAness and concordance of clinical features with BRCA1-mutation carriers. Br J Cancer 108: 2172-2177, 2013.

8. Hu XC, Zhang J, Xu BH, Cai L, Ragaz J, Wang ZH, Wang BY, Teng YE, Tong ZS, Pan YY, et al: Cisplatin plus gemcitabine versus paclitaxel plus gemcitabine as first-line therapy for metastatic triple-negative breast cancer (CBCSG006): A randomised, open-label, multicentre, phase 3 trial. Lancet Oncol 16: 436-446, 2015.

9. Fan Y, Xu BH, Yuan P, Ma F, Wang JY, Ding XY, Zhang P, Li Q and Cai RG: Doxetaxel cisplatin might be superior to docetaxel capecitabine in the first line treatment of metastastic triple negative breast cancer. Ann Oncol 24: 1219-1225, 2013.

10. Gelmon K, Dent R, Mackey JR, Laing K, McLeod D and Verma S: Target triple negative breast cancer: Optimizing therapeutic outcomes. Ann Oncol 23: 2223-2234, 2012.

11. Zhang J, Wang Z, Hu X, Wang B, Wang L, Yang W, Liu Y, Liu G, Di G, Hu Z, et al: Cisplatin and gemcitabine as the first line therapy in metastatic triple negative breast cancer. Int $\mathrm{J}$ Cancer 136: 204-211, 2015.

12. Taniguchi T, Tischkowitz M, Ameziane N, Hodgson SV, Mathew CG, Joenje H, Mok SC and D'Andrea AD: Disruption of the Fanconi anemia-BRCA pathway in cisplatin-sensitive ovarian tumors. Nat Med 9: 568-574, 2003

13. Wei M, Xu J, Dignam J, Nanda R, Sveen L, Fackenthal J, Grushko TA and Olopade OI: Estrogen receptor alpha, BRCA1, and FANCF promoter methylation occur in distinct subsets of sporadic breast cancers. Breast Cancer Res Treat 111: 113-120, 2008.

14. Jing MX, Mao XY, Li C, Wei J, Liu C and Jin F: Estrogen receptor-alpha promoter methylation in sporadic basal-like breast cancer of Chinese women. Tumor Biol 32: 713-719, 2011.

15. Taniguchi T, Kakkar AK, Tuddenham EG, Williamson RC and Lemoine NR: Enhanced expression of urokinase receptor induced through the tissue factor-factor via pathway in human pancreatic cancer. Cancer Res 58: 4461-4467, 1998.

16. Gradishar WJ, Anderson BO, Balassanian R, Blair SL, Burstein HJ, Cyr A, Elias AD, Farrar WB, Forero A, Giordano $\mathrm{SH}$, et al: NCCN guidelines insights breast cancer, version 1.2016. J Natl Compr Canc Netw 13: 1475-1485, 2015.

17. Seitz S, Rick FG, Schally AV, Treszl A, Hohla F, Szalontay L, Zarandi M, Ortmann O, Engel JB and Buchholz S: Combination of GHRH antagonists and docetaxel shows experimental effectiveness for the treatment of triple-negative breast cancers. Oncol Rep 30: 413-418, 2013.

18. van de Water W, Seynaeve C, Bastiaannet E, Markopoulos C, Jones SE, Rea D, Hasenburg A, Putter H, Hille ET, Paridaens R, et al: Elderly postmenopausal patients with breast cancer are at increased risk for distant recurrence: A tamoxifen exemestane adjuvant multinational study analysis. Oncologist 18: 8-13, 2013.

19. Makubate B, Donnan PT, Dewar JA, Thompson AM and McCowan C: Cohort study of adherence to adjuvant endocrine therapy, breast cancer recurrence and mortality. $\mathrm{Br}$ J Cancer 108: 1515-1524, 2013

20. Adams S, Gray RJ, Demaria S, Goldstein L, Perez EA, Shulman LN, Martino S, Wang M, Jones VE, Saphner TJ, et al: Prognostic value of tumor-infiltrating lymphocytes in triple negative breast cancer from two phase III randomized adjuvant breast cancer trail: ECOG 2197 and ECOG 1199. J Clin Oncol 32: 2959-2966, 2014.

21. Schneider BP, Zhao F, Wang M, Stearns V, Martino S, Jones V Perez EA, Saphner T, Wolff AC, Sledge GW Jr, et al: Neuropathy is not associated with clinical outcomes in patients receiving adjuvant taxane-containing therapy for operable breast cancer. J Clin Oncol 30: 3051-3057, 2012.

22. Johnson N, Johnson SF, Yao W, Li YC, Choi YE, Bernhardy AJ Wang Y, Capelletti M, Sarosiek KA, Moreau LA, et al: Stabilization of mutant BRCA1 protein confers PARP inhibitor and platinum resistance. Proc Natl Acad Sci USA 110: 17041-17046, 2013

23. Julka PK, Chacko RT, Nag S, Parshad R, Nair A, Oh DS, Hu Z, Koppiker CB, Nair S, Dawar R, et al: A phase II study of sequential neoadjuvant gemcitabine plus doxorubicin followed by gemcitabine plus cisplatin in patients with operable breast cancer: Prediction of response using molecular profiling. Br J Cancer 98: 1327-1335, 2008. 
24. Staudacher L, Cottu PH, Diéras V, Vincent-Salomon A Guilhaume MN, Escalup L, Dorval T, Beuzeboc P, Mignot L and Pierga JY: Platinum-based chemotherapy in metastatic triple-negative breast cancer: The institut curie experience. Ann Oncol 22: 848-856, 2011.

25. Wang K, Xie S, Ren Y, Xia H, Zhang X and He J: Establishment of a bioluminescent MDA-MB-231 cell line for human triple-negative breast cancer research. Oncol Rep 27: 1981-1989, 2012.

26. Al Dhaheri Y, Eid A, AbuQamar S, Attoub S, Khasawneh M, Aiche G, Hisaindee $S$ and Iratni R: Mitotic arrest and apoptosis in breast cancer cells induced by origanum majorana extract: Upregulation of TNF- $\alpha$ and downregulation of survivin and mutant p53. PLoS One 8: e56649, 2013

27. Ma CX, Cai S, Li S, Ryan CE, Guo Z, Schaiff WT, Lin L, Lin L, Hoog J, Goiffon RJ, Prat A, et al: Targeting CHK1 in p53-deficient triple-negative breast cancer is therapeutically beneficial in human-in-mouse tumor models. J Clin Invest 122 : $1541-1552,2012$

28. Deb S, Wong SQ, Li J, Do H, Weiss J, Byrne D, Chakrabarti A, Bosma T, kConFab Investigators, Fellowes A, et al: Mutational profiling of familial male breast cancers reveals similarities with luminal A female breast cancer with rare TP53 mutations. Br J Cancer 111: 2351-2360, 2014

29. Michils G, Hollants S, Dehaspe L, Van Houdt J, Bidet Y, Uhrhammer N, Bignon YJ, Vermeesch JR, Cuppens H and Matthijs G: Molecular analysis of the breast cancer genes BRCA1 and BRCA2 using amplicon- based massive parallel pyrosequencing. J Mol Diagn 14: 623-630, 2012.

30. Murphy CG and Moynahan ME: BRCA gene structure and function in tumor suppression: A repair-centric perspective. Cancer J 16: 39-47, 2010.

31. Oplustilova L, Wolanin K, Mistrik M, Korinkova G, Simkova D, Bouchal J, Lenobel R, Bartkova J, Lau A, O'Connor MJ, et al: Evaluation of candidate biomarkers to predict cancer cell sensitivity or resistance to PARP-1 inhibitor treatment. Cell Cycle 11: 3837-3850, 2012

32. Choi DH, Lee MH, Bale AE, Carter D and Haffty BG: Incidence of BRCA1 and BRCA2 mutations in young korean breast cancer patients. J Clin Oncol 22: 1638-1645, 2004.

33. Lord CJ and Ashworth A: Mechanisms of resistance to therapies targeting BRCA-mutant cancers. Nat Med 19: 1381-1388, 2013.

34. Mao XY, Fan CF, Zheng HC, Wei J, Yao F and Jin F: p53 nuclear accumulation and ERalpha expression in ductal hyperplasia of breast in a cohort of 215 chinese women. J Exp Clin Cancer Res 29: 112, 2010.

35. Mao XY, Chen H, Wang H, Wei J, Liu C, Zheng HC, Yao F and Jin F: MTA1 expression correlates significantly with ER-alpha methylation in breast cancer. Tumour Biol 33: 1565-1572, 2012.

36. Zhao L, Wang L, Jin F, Ma W, Ren J, Wen X, He M, Sun M, Tang $\mathrm{H}$ and Wei M: Silencing of estrogen receptor alpha (ERalpha) gene by promoter hypermethylation is a frequent event in Chinese women with sporadic breast cancer. Breast Cancer Res Treat 117: 253-259, 2009

37. Jin F, Liu C, Guo Y, Chen $\mathrm{H}$ and $\mathrm{Wu}$ Y: Clinical implications of Girdin and PI3K protein expression in breast cancer. Oncol Lett 5: 1549-1553, 2013

38. Sahab ZJ, Man YG, Byers SW and Sang QX: Putative biomarkers and targets of estrogen receptor negative human breast cancer Int J Mol Sci 12: 4504-4521, 2011.

39. Pachmann K, Camara O, Kroll T, Gajda M, Gellner AK, Wotschadlo J and Runnebaum IB: Efficacy control of therapy using circulating epithelial tumor cells (CETC) as 'liquid biopsy': Trastuzumab in HER2/neu-positive breast carcinoma. J Cancer Res Clin Oncol 137: 1317-1327, 2011.
40. Soria JC, Blay JY, Spano JP, Pivot X, Coscas Y and Khayat D: Added value of molecular targeted agents in oncology. Ann Oncol 22: 1703-1716, 2011.

41. De P, Sun Y, Carlson JH, Friedman LS, Leyland-Jones BR and Dey N: Doubling down on the PI3K-AKT-mTOR pathway enhances the antitumor efficacy of PARP inhibitor in triple negative breast cancer model beyond BRCA-ness. Neoplasia 16: 43-72, 2014.

42. Konishi H, Mohseni M, Tamaki A, Garay JP, Croessmann S, Karnan S, Ota A, Wong HY, Konishi Y, Karakas B, et al: Mutation of a single allele of the cancer susceptibility gene BRCA1 leads to genomic instability in human breast epithelial cells. Proc Nat Acad Sci USA 108: 17773-17778, 2011.

43. Sy SM, Huen MS and Chen J: PALB2 is an integral component of the BRCA complex required for homologous recombination repair. Proc Natl Acad Sci USA 106: 7155-7160, 2009

44. Stefansson OA, Jonasson JG, Johannsson OT, Olafsdottir K, Steinarsdottir M, Valgeirsdottir S and Eyfjord JE: Genomic profiling of breast tumours in relation to BRCA abnormalities and phenotypes. Breast Cancer Res 11: R47, 2009.

45. Albarakati N, Abdel-Fatah TM, Doherty R, Russell R, Agarwal D, Moseley P, Perry C, Arora A, Alsubhi N, Seedhouse C, et al: Targeting BRCA1-BER deficient breast cancer by ATM or DNA-PKcs blockade either alone or in combination with cisplatin for personalized therapy. Mol Oncol 9: 204-217, 2015.

46. Tommiska J, Bartkova J, Heinonen M, Hautala L, Kilpivaara O, Eerola H, Aittomäki K, Hofstetter B, Lukas J, von Smitten K, et al: The DNA damage signalling kinase ATM is aberrantly reduced or lost in BRCA1/BRCA2-deficient and ER/PR/ERBB2-triple-negative breast cancer. Oncogene 27: 2501-2506, 2008.

47. Murria R, Palanca S, de Juan I, Egoavil C, Alenda C, García-Casado Z, Juan MJ, Sánchez AB, Santaballa A, Chirivella I, et al: Methylation of tumor suppressor genes is related with copy number aberrations in breast cancer. Am J Cancer Res 5: 375-385, 2014

48. Bueno RC, Canevari RA, Villacis RA, Domingues MA, Caldeira JR, Rocha RM, Drigo SA and Rogatto SR: ATM down-regulation is associated with poor prognosis in sporadic breast carcinomas. Ann Oncol 25: 69-75, 2014.

49. Jiang H, Reinhardt HC, Bartkova J, Tommiska J, Blomgvist C, Nevanlinna H, Bartek J, Yaffe MB and Hemann MT: The combined status of ATM and p53 link tumor development with therapeutic response. Genes Dev 23: 1895-1909, 2009.

50. Chan KY, Ozcelik H, Cheung AN, Ngan HY and Khoo US: Epigenetic factors controlling the BRCA1 and BRCA2 genes in sporadic ovarian cancer. Cancer Res 62: 4151-4156, 2002.

51. Haitjema A, Brandt BW, Ameziane N, May P, Heringa J, de Winter JP, Joenje H and Dorsman JC: A protein prioritization approach tailored for the FA/BRCA pathway. PLoS One 8: e62017, 2013

52. Mote PA, Leary JA, Avery KA, Sandelin K, Chenvix-Trench G, Kirk JA and Clarke CL; kConFab Investigators: Germ-line mutations in BRCA1 or BRCA2 in the normal breast are associated with altered expression of estrogen-responsive proteins and the predominance of progesterone receptor A. Genes Chromosomes Cancer 39: 236-248, 2004.

This work is licensed under a Creative Commons Attribution-NonCommercial-NoDerivatives 4.0 International (CC BY-NC-ND 4.0) License. 